\title{
Exploration of Influencing Factors for Homestay Industry from the Perspective of Global Tourism -- With the Example of Dali
}

\author{
Meihua Wang ${ }^{1, a}$ \\ ${ }^{1}$ College of Business Administration, Hunan University, Hunan 410082, China \\ awelcomemeihua@163.com
}

\begin{abstract}
Keywords: Global tourism; Homestay industry; Dali; Influencing factor
Abstract. Global tourism is the important guiding principle for country tourism development in the new era. Homestay industry of Dali has been developed rapidly in recent years, however, some problems occurred. From the perspective of influencing factors, this paper probes into the development status and the existing problems and provides a sustainable development path for homestay industry in Dali in combination with the macro background of China' s homestay tourism development.
\end{abstract}

\section{Introduction}

The so-called global tourism refers to the tourism pattern that brings in local residents, government departments and enterprises into a system and allows all of them to participate in the development ${ }^{[1-2]}$. The definition of global tourism was put forward in the Dalian' $s$ topic titled "Construction of Future Tourist City" in 2016, which was the extension of the definition of "whole area urbanization" [3]. After that, it was introduced in many large tourist cities and then the mode for future development of tourist cities from the perspective of global tourism was brought up to enhance local tourism development quality and enhance urban economic development. Through a long-period of development, Dali' s tourism has become the main force of Yunnan Province and even central and western region of China in economic development. In spite of its achievements in tourism, the development in homestay tourism industry is not satisfactory but affected and restrained by some factors ${ }^{[4]}$.

\section{Analysis of Influencing Factors for homestay Industry in Dali}

The influencing factors for homestay industry in Dali mainly cover two types: first, factors concerning tourists, as shown in Table 1.

Tab. 1 The factors influencing the development of the industry based on the passenger point of Dali Hostel

\begin{tabular}{|l|l|l|}
\hline & \multicolumn{1}{|c|}{ Cultural Depth } & Product Experience \\
\hline $\begin{array}{l}\text { Influencing } \\
\text { Factor }\end{array}$ & $\begin{array}{l}\text { Country and homestay } \\
\text { cultural depth are to be } \\
\text { deepened }\end{array}$ & $\begin{array}{l}\text { Blindly follow the trend, provide } \\
\text { little forms and shall further improve } \\
\text { experience satisfaction }\end{array}$ \\
\hline
\end{tabular}

The specific analysis of the influencing factors concerning tourists is given as follows:

(I) lack of homestay cultural depth: As is well known that, Dali is a famous tourist city in China and characterized by enchanting natural landscape and exotic minority culture. People traveling to Dali firstly feel the cultural landscape, thus, the focus of Dali's homestay tourism shall be laid on exploration of the local ethnic features. However, at the present, the tourism development in Dali is filled with urban color with little characteristic culture, which is related to urbanization and economic development need, also a taboo for development of homestay tourism in Dali. 
(II) Lack of tourists' product experience: tourism products spring up rapidly and become out of style really soon. And different places easily follow suit and imitate each other in developing tourism industry, it is also true of Dali', where the development of unique local customs and practices, diet and custom culture is not given to due importance, and the pattern of tourist attractions and tourism products are similar to those in other scenic spots in China. homestay culture includes farming culture, folk arts and crafts culture, folk architecture, customs and habits. As a famous minority enclave, Dali is enjoys a high reputation in our country for its homestay culture, which is a part of the precious essence of China's traditional culture and the foundation of homestay tourism development of Dali. Nevertheless, in order to cater the general trend of tourism development, Dali is now blindly seeking urbanization and paying a little attention to exploration of its local homestay culture. In the city center, local cultural features are almost discarded to meet the tourists' requirements of comfort and convenience, thus, the original features of homestay tourism are lost. In addition, development of unique homestay culture, original farming culture, exquisite handicraft technology are only carried out on a superficial level without lasting charm and depth. The above phenomena have led to serious waste of homestay tourism resources of Dali.

Tab. 2 The influencing factors concerning local resource exploitation

\begin{tabular}{|c|c|c|}
\hline & Natural Landscape & $\begin{array}{l}\text { Exploitation and } \\
\text { Transformation }\end{array}$ \\
\hline Influencing Factor & $\begin{array}{c}\text { Scenic spots remain } \\
\text { unchanged and rigid for a } \\
\text { long time, tourist experience } \\
\text { turn to be dissatisfactory }\end{array}$ & $\begin{array}{c}\text { Inappropriately seek for } \\
\text { economic benefits and blindly } \\
\text { exploit resources }\end{array}$ \\
\hline
\end{tabular}

(III) Scenic spots remain unchanged and rigid for a long time: One of the distinctive of Dali in its tourism development is scenic spots all over the city, namely “ beautiful scenery all around and attracting landscape everyone. There are more than 130 scenic spots in different size which come in sight nearly every few steps; besides, due to peculiarity of ethnic customs, for tourists from different places, daily "food clothing shelter and transportation" of the residents in Dali inevitably become an important part of tourism resources. However, the tourism experience only leave a superficial impression on the tourists, for there are excessive urban cultural characteristics added to the original state, which unduly replace product experience development as the focus in spite that the city is richly endowed by nature. This paper believes that Dali shall focus on, further develop local natural landscape, customs and practices, and manners and feelings and restore them to the original state to become the mainstream of homestay industry of Dali in the future and make due contribution to development of Dali's tourism industry.

(IV) Transformation and exploitation of natural landscape in a blind way: tourism development of Dali shall center on natural scenery and cultural customs, but the government, in pursuit of substantial rebuilding of forest land and vegetation, is now eagerly seeking for economic benefits without following the scientific guiding principle of sustainable development. Consequently, vegetation coverage is decreased sharply, rare animals and plants resources are endangered, and unfortunately, more and more natural landscape will be transformed into something "bears no resemblance to things of this kind” by people seeking for economic benefits. In this case, serious damage will be made to development of homestay tourism industry of Dali.

\section{Feasible Suggestions on homestay tourism development of Dali}

Feasible suggestions on homestay tourism development of Dali can be cover two types. First, suggestions to be implemented at government level and from cultural perspective, as shown in Table 3: 
Tab.3 Feasible suggestions on homestay tourism development of Dali

\begin{tabular}{|c|c|c|}
\hline & Government Level & Culture Perspective \\
\hline $\begin{array}{c}\text { Feasible } \\
\text { Suggestion }\end{array}$ & $\begin{array}{l}\text { Scientific planning of a } \\
\text { new homestay tourism } \\
\text { development system of Dali }\end{array}$ & $\begin{array}{l}\text { Construction of an industry system } \\
\text { oriented on homestay Tourism culture } \\
\text { of Dali }\end{array}$ \\
\hline
\end{tabular}

(I) Scientific planning of a new homestay tourism development system of Dali: in the global tourism era, Dali's homestay tourism shall make horizontal and vertical exploration from the basic point of homestay culture to integrate all sots of tourism resources and form a sustainable tourism resource system. In addition, the core principle of global tourism shall be regarded as the guiding theory with proper adjustment made to local conditions so as to make general development layout and planning with the entire homestay tourism resources as a comprehensive tourism system.

(II) Construction of an industry system oriented on homestay Tourism culture of Dali to enhance tourists' experience satisfaction. The local homestay culture of Dali shall be kept and original flavor of local customs and practices shall be preserved. Local ecology culture and homestay culture shall be developed as landmarks with the characteristics being intensified and form and content of experience being bettered so as to improve service quality. By thus doing, can we develop the resources peculiar to Dali into unique tourism products to attract tourists and build word-of-mouth tourism effects.

The second type of suggestions are to be implemented from the perspective of environmental protection and sustainable development, as shown in Table 4:

Tab. 4 Suggestions from the perspective of environmental protection and sustainable development

\begin{tabular}{|c|l|l|}
\hline & Ecological Tourism & $\begin{array}{l}\text { Advanced Experience } \\
\text { for Reference }\end{array}$ \\
\hline $\begin{array}{c}\text { Feasible } \\
\text { Suggestion }\end{array}$ & $\begin{array}{l}\text { Ecological tourism is to be } \\
\text { regarded as the premise of homestay } \\
\text { tourism development }\end{array}$ & $\begin{array}{l}\text { with the high attention } \\
\text { paid to ecological } \\
\text { environment protection }\end{array}$ \\
\hline
\end{tabular}

(I) Development of homestay tourism of Dali shall be combined with ecological tourism to facilitate more innovative homestay tourism development with ecological protection so as to make the superior resources become the steady stream of supply for development of global tourism in the future. Meanwhile, repair and protection of the public tourism resources which have been recognized shall be provided; resource development, integration, optimization and formation of a system of the undeveloped tourism resources shall be ensured in line with sustainable development strategy from the perspective of global tourism. Besides, new ecological spots shall be developed, for instance, new ecological zones can be built in the places with environmental advantage but without characteristic advantage, such as barren lands and dry ditches, which can be built into new botanic gardens and fish ponds. Only by combination of homestay tourism and ecological environment protection and development, the sustainable development of homestay tourism can be promising.

(II) Experience in similar areas can be used for reference with proper adjustments to local situations. The current situation and development trend of homestay tourism of Dali shall be taken into consideration to build a path for steady development step by step. Dali, Xishuangbanna and Jiuzhaigou Valley have something in common, and the other two places are provided with substantial achievements in environmental protection during tourism development and build a sustainable industry chain of tourism, local economic development and employment of farmers. Dali can learn from experience suitable for itself and make proper adjustment to realize long-term development of its homestay tourism.

\section{References}

[1] Hamzah A. Chapter 16 - Malaysian Homestays from the Perspective of Young Japanese Tourists: The Quest for Furusato[J]. Asian Tourism, 2008, 238(1):193-207. 
[2] Hamzah A, Mohamed B. Finding Furusato in Malaysia : The Attractiveness of Homestays in Malaysia from the Perspective of Japanese Touritsts[J]. Journal of Environmental Economics \& Management, 2006, 40(3):251-274.

[3] Getz D, Carlsen J. Family business in tourism: State of the Art[J]. Annals of Tourism Research, 2005, 32(1):237-258.

[4] Knight S M, Schmidt-Rinehart B C. Enhancing the Homestay: Study Abroad from the Host Family's Perspective[J]. Foreign Language Annals, 2002, 35(2):190-201. 